\title{
Spring Sparkle and the Cock-Bird Shriek
}

Yesterday the winter web, the winter woven, wind and wind. Today, two or three blackbirds sang some tentative strains;

Sheer in the sun they passed

Themselves flying into themselves.

Neighbors are coming out, sitting on their porches,

Crossing the street to visit, each in prismatic guise.

The bubbling sun bubbles up, Spring is a process.

I find at eighty-four a poignancy in all movement.

We set between issue and return, catching at good-bye.

The swarm of thoughts, the swarm of dreams wholly

Containing the mind, the rhythm of a celestial pantomime.

Providence that had so long the care of reality, Should see it now: Things are but names assigned

To lustings for self, a process unquestionable as death.

So reality, once a stricture, is now a matter

Of taste, a taste in the head, where ideas are a memory.

There is no friend in belief when the shapes are wrong, And the sounds are false. And then there is Time, Which grudges the living that they live, then grudges Them their death; no shift of realities has changed this.

Such is the immense disorder of truth that hangs in the brain. Let earth take charge, while the hours lead on, May this movement spare me a final humiliation. 